\title{
Nostradamus's Prophecies and Uncertainty of Future
}

\author{
Aleksandr Yeremenko \\ Doctor in Philosophy, Professor, Head of Philosophy Department, \\ National University “Odessa Law Academy” (Odessa, Ukraine) \\ E-mail: alyeremenko@gmail.com \\ https://orcid.org/0000-0002-2922-0643
}

\begin{abstract}
The article interprets Michel Nostradamus's quatrains in terms of the eventeme theory developed by the author. An eventeme is an abstract possibility of various single events. The main hypothesis of the article is that Nostradamus described eventemes as single events and filled them with details, thus making an illusion of a prophecy. It was not the only method of Nostradamus's work, though. Believing in recurrence of historical events, Nostradamus extrapolated past events to the future. This paper analyses some quatrains representing single manifestations of a certain eventeme. The article contains a fragment of the quatrain table where the author reflected both event-driven and eventematic content of the Centuries. The research demonstrates the differences between a prophecy, a foresight and a prediction. The author justifies a thesis on impossibility of exact prediction of single events due to uncertainty of the future.
\end{abstract}

Keywords: Nostradamus, event, eventeme, prophecy, prediction, uncertainty of future

Received: March 12, 2019; accepted: April 20, 2019

Philosophy and Cosmology, Volume 24, 2020: 170-179.

https://doi.org/10.29202/phil-cosm/24/17

\section{Introduction}

Michel Nostradamus is one of the cult characters of the world culture. No doubt, it is the apologetic tendency that predominates in investigating the Provençal prophet's creative work. However, we have joined the critical tendency. The modern researchers who sided the critical tendency are Pierre Brind'Amour (Brind'Amour, 1993), Elmar Gruber (Gruber, 2003), David Shepheard (Shepheard, 1986), Peter Lemesurier (Lemesurier, 2003) and Anna Carlstedt (Carlstedt, 2005). With some reservation, we could refer to the critical tendency a work by Aleksey Penzensky (Penzensky, 2007).

In this research, we are going to apply to quatrain investigation our own methodology of history's philosophical interpretation. The main point of the methodology is a concept of "eventeme" that we have introduced in the scientific world (Yeremenko, 2005). Having applied this concept to quatrain analysis, we shall try to demonstrate how it works in interpreting historical events and facts. We are also going to justify the possibility of

(C) Yeremenko, Aleksandr, 2020 
predicting abstract event figures and principal impossibility of predicting single events with rational methods.

\section{Eventeme Concept}

We believe in seeming principal uniqueness and soleness of any historical event. We are of the opinion that the principle that unites events and allows to generalise them is not only possible to find but it should be found. Such a principle is a clear structure of events. We suggest the name "eventeme" for the basic event classes that differ in their structural features.

Among the modern thinkers, Gilles Deleuze and Reinhart Koselleck are the closest in understanding the essence of an eventeme. Gilles Deleuze views a battle as a model of "an event in its point". "Besides, the battle itself floats over its own field. It is neutral in relation to all its actualisations in time, it is neutral and dispassionate to winners and losers, cowards and men of courage; and thus it is even more frightening. It is never in the present, but it is always either about to happen or it has already happened. A battle is perceptible for an anonymous will only — a will the battle has inspired itself" (Deleuze, 1995: 128-129).

One can say that in the same way as the "neutral and dispassionate" battle described by Gilles Deleuze is related to single battles, a "neutral and dispassionate" eventeme is related to single events.

In another episode of Gilles Deleuze's discourse, he does not only guess but actually introduces a concept of eventeme, without naming it an "eventeme." "Events are ideal. Novalis states somewhere in his works that there are two courses of events: one of them is ideal; the other one is real and imperfect. Examples can be ideal Protestantism and real Lutheranism. However, this difference is not between the two types of events, it is rather a difference between an ideal event and its status quo spatiotemporal realisation. It is between an event and an accident. Events are ideal singularities communicating in the same Event. Thus, they are true eternally. Their time is never the present that urges them to happen. Events are rather invariably in the boundless Eon, in the Infinitive" (Deleuze, 1995: 74-75).

If to briefly set forth the main point of our vision of history, we will have to state again: there are seemingly two strata, or two dimensions, or two levels of history: a level of constantly continuing forms, or structure-forming principles, or empty "reservoirs" of events — and a level of real single events.

In Reinhart Koselleck's works, an important part is differentiation of single events and stable structures that make the events possible. Each single event taken as a whole is unique, the one and only. However, event structures recur in history. On the one hand, they are internal structures of events, on the other hand - they are structures of event sequences. Reinhart Koselleck names these structures in different ways: "formal categories" postulated as conditions for possible stories (Koselleck, 2005: 159); stable event models (Koselleck, 2005: 164); recurring formal structures (Koselleck, 2006: 233); continuous structures of historical experience (Koselleck, 2006: 246).

\section{On Methods of Michel Nostradamus's Work}

In terms of the eventeme theory, we can formulate the main hypothesis of our research. Michel Nostradamus described eventemes as single events and filled them with details, thus making an illusion of a prophecy. Moreover, the Provençal prophet would fill the quatrains with various, sometimes controversial details. At the same time, he strived for multivalued uncertainty of details, to knowingly provide for multiple interpretations of the quatrains. 
Here two explanations are necessary. First, we are not eager to say that Michel Nostradamus developed a theory of eventemes and used it consciously in composing his quatrains. Believing in the event recurrence, Michel Nostradamus understood that it is possible to single out a common sense of similar events, so to say, to abstract from details, and then, vice versa, to fill with details. The eventeme approach is as though implied in the idea of event recurrence.

This is followed by the second explanation. We by no means assume that all the quatrains are composed by the "eventeme" method. We believe that Michel Nostradamus practised several ways of composing his predictions. 1. Describe past events as future events. 2. Describe the abstract sense of an event (eventeme) as a single event. 3. Describe single events on the assumption of understanding the general tendency of event development. 4. Describe the visions he sometimes saw.

Among the modern investigators, the eventeme method is best analysed by Anna Carlstedt in her work "The Oracular Poetry of Nostradamus: Language, Style and Genre of The Centuries (Carlstedt, 2005).

Anna Carlstedt singles out three main themes of Michel Nostradamus's prophecies: war, government (secular and clerical) and catastrophe. These are subdivided into the following subthemes: 1) war: battle, victory, defeat; 2) government: governor assassination, proclamation (accession to power) of a new governor, bad government; 3) catastrophe: disease, hunger, natural cataclysms (Carlstedt, 2005: 113). In general, we consider Anna Carlstedt's classification to be successful. The themes singled out by the Swedish researcher, as well as some other themes, are what we call eventemes.

Michel Nostradamus extrapolates to the future the realia of his time, which is the peculiarities of social and political, religious and cultural life of the $16^{\text {th }}$ century. This is what Pierre Brind'Amour and Elmar Gruber paid attention to. For instance, Pierre Brind'Amour characterises The Centuries in such a way: "This work of Nostradamus makes sense; I would rather say it is transparent. It reflects the deepest obsessions of the people of that time: a fear of natural cataclysms (earthquakes, floods, droughts...) and their absolutised forms (deluges, overall fire, the end of the world), a fear of diseases (especially plague), a fear of war (wars with other states, the Turkish threat in particular, religious wars, civil riots), anxiety of tokens (births of monsters, comets, eclipses), a fear of seeing the Antichrist, etc. These obsessive ideas combined with ordinary political troubles (this day one prince is killed, that day another prince is imprisoned, the other day sees a conspiracy) make a large part of The Centuries" (Brind'Amour, 1993: 5-6).

If to assume that there are not only absolutised forms of ideas, but also absolutised forms of real historical events, these will be eventemes.

\section{Eventematic Figures In the Quatrains}

All the quatrains have more or less clear eventeme structure what is reflected in our table of quatrains. Some of the quatrains are almost simple description of a clear eventeme. Almost simple, but never, since Michel Nostradamus always somehow saturated a quatrain with details. This saturation has a double goal. First, details create a feeling of a reliable prediction: if a prophet sees the details of an event, no doubt he sees the event itself. Second, details darken the sense of the event, creating a field of various interpretations. The variety of interpretations is conditioned by, firstly, the variety of details what increases the probability of coincidence of any detail with reality. Secondly, details themselves are often unclear; they are saturated with metaphorical or symbolic sense, thus providing for a possibility of various interpretations. 
Nevertheless, some quatrains are "more" eventematic than others. For understanding the essence of a historical change itself, quite interesting is Quatrain III, 46:

The sky (of Plancus' city) forebodes to us

Through clear signs and fixed stars,

That the time of its sudden change is approaching,

Neither for its good, nor for its evils.

Thus, celestial signs predict to a certain town (in Aleksey Penzensky's opinion, this town is Lyons, as it should be read a "Plancus's town" since Lyons was founded by Lucius Munatius Plancus (Penzensky, 2007: 244)) sudden changes (metamorphoses), and these changes will lead to neither the good, nor the bad (as assumed by Aleksey Penzensky "neither the best nor the worst" (Penzensky, 2007)). How can this be possible? Any change, especially a historical change is a turn for the better or for the worse. It is wrong: such an approach is too evaluative. If we want to realise the pure essence of a change, we should, so to say, "Leave aside" evaluative judgements. A change is a transition of this into that, if it is a quality change, or it is the appearance of elements of that in this, if it is a quantity change. It is not always possible to evaluate this and that as the best and the worst. With this approach, we darken the essence of the change itself. When we think of a change "neither to the good nor to the bad", we think of an eventematic essence of the historical change.

Some quatrains can illustrate the binary structure of an eventeme. Let us take Quatrain YIII, 65:

The old man disappointed in his main hope, will attain to the leadership of his Empire.

Twenty months he will hold rule with great force,

a tyrant, cruel, giving way to one worse.

At first sight, there is nothing special about it: a trivial eventeme "a change of a governor", more precisely "a change of a tyrant". But further specification is hampered. As assumed by Miroslav Adamchik, we find a difference in Line 4: "A ruthless despot who replaced even a worse despot [leaving behind himself even a worse one]". It is not clear: whether a ruthless old man will replace even a worse tyrant, or vice versa, he will be replaced by even a worse one. We are still in difficulties: whether the prediction concerns "from the frying pan and into the flame", or "from the flame and onto the frying pan". It is clear that both variants are not good, but there is a difference between them, though.

It is not impossible that the abovementioned ambiguity is caused by an inaccurate translation. But it is not also impossible that Michel Nostradamus deliberately strived for the ambiguity of statements, making them possible to interpret in two ways: either a repulsive governor will be replaced by a bad one, or a bad governor will be replaced by a repulsive one (let us remember the classic of the genre - the prediction by the Oracle of Delphi to Croesus, the king of Lydia, concerning that, having crossed the boundary river, he will destroy a powerful kingdom).

Some of the researchers came close to understanding the eventeme methods of studying the quatrains. It is surprising that such understanding did not hamper their apologetic attitude to the "prophetic" gift of Michel Nostradamus. Quatrain IY, 83 describes the escape of a military leader in a night battle: 
Combat by night the valiant captain

Conquered will flee few people conquered:

His people stirred up, sedition not in vain,

His own son will hold him besieged.

The word "valiant (captain)" is used ironically, of course. John Hogue comments on this quatrain in the following way: "Considering the fact that over the past 440 years there were more than a thousand wars with a countless number of night battles, the incident mentioned in the quatrain can take place in any of them" (Hogue, 2002).

Absolutely correct! But then it is not at all possible to consider this quatrain to be prophetic. If we analyse the eventeme "night battle" or say "vengeance to the commander who fled", then their eventematic feeling will appear rather impressive. Then what exactly does Michel Nostradamus predict?

Sometimes an event described in a quatrain resembles not only an eventeme but also a mythologema or a stable image of various literary traditions. For instance, Quatrain X, 43:

Too much good times, too much of royal goodness,

Ones made and unmade, quick, sudden, neglectful:

Lightly will he believe falsely of his loyal wife,

He put to death through his benevolence.

So, regarding events: a far too kind king, having believed a slander, puts to death a faithful wife. First of all, here we deal again with an ambiguous, if you prefer, a double eventeme in one quatrain. What is the sense of the situation: "execution of a faithful but slandered wife" or "excessive kindness is ruinous"? One can interpret this as a concretisation of an abstract eventeme in a variant: "excessive kindness is ruinous, for example, a kind king puts to death a slandered wife" (compare with X, 35). If to focus on the execution of the slandered wife, we will have a motive of sufferings of an innocent virtuous woman that is widely spread in mythology and literature: Psyche created by Apuleius, suffering abandoned wives in medieval ballads, Hero and Desdemona created by William Shakespeare and others.

Among the eventematic quatrains, of special interest is Quatrain IX, 66:

There will be peace, union and change,

Estates, offices, low high and high very low:

To prepare a trip, the first offspring torment,

War to cease, civil process, debates.

Here is a complete set of eventemes - to fit every taste: peace, union, changes, end of war (struggle); lower classes will rise, higher classes will fall (as assumed by Miroslav Adamchik: "States and Churches will rise from the low and fall from the high"). Here is a certain travel (pilgrimage) as well, an even more mysterious fruit; here is a civil process, pleadings (debates?). In general, the story goes on in all its shapes and sizes. It is very convenient for bringing various events under such "predictions". An eventematic sense of the quatrain can be formulated as follows: "up and down the wheel of fortune".

\section{Eventemes and Tendencies}

Aleksey Penzensky suggests the following idea: "Investigation of "Prophecies" shows that Nostradamus was able to foresee global tendencies but he gave in to particulars" (Penzensky, 2007). We do not want to be hypercritical, but we are of the opinion that Michel 
Nostradamus could not see clearly the global tendencies, but if to call things as they are - he could see the tendencies in a quite unsteady and vague way. His vision abounds in mistakes: he often "foresees" a tendency, which will fade away in the future. At the same time, he completely ignores a tendency that will soon appear and become powerful. It is obvious that the Provençal prophet did not predict the shift of the power centres in the world politics. $\mathrm{He}$ says practically nothing about the USA, Russia; he remains silent about China and Japan. The lion's share of the quatrains is dedicated to the Mediterranean: there is such an impression that Nostradamus considered this region to be the most important arena of world events in the immediate and distant future. The Provençal prophet does not as well foresee the crashes of thrones and feudal orders, the triumph of the commons, and the development of industry on the rails of the bourgeois economic system.

Here, of course, an objection suggests itself: how could he not foresee the crash of thrones? The Centuries are just stuffed with pictures of rebellions, revolutions, overthrows and executions of monarchs and other social cataclysms of the kind. That is right! However, this is not a crash of thrones as such. This is not the collapse of monarchy as a system of state. A monarch's overthrow, a change of dynasty, dying away of a rank family - a similar whirl of events is projected by Nostradamus to the future. However, why does not he say anything about France, which is to turn from monarchy to republic, or England, which is to become a constitutional monarchy but actually a republic? Why does not he predict that the Holy Roman Empire, the German nation will be replaced by a more consolidated German state, but it will be a republican state. Why is there not a word about the republic of the USA the $20^{\text {th }}$ century master of political destinies? Repeatedly, Nostradamus paints vivid pictures of religious wars. However, why does not he say anything about the lowering intensity of religious conflicts in the $18^{\text {th }}-20^{\text {th }}$ centuries? Consequently, Michel Nostradamus predicts exactly eventemes: wars, revolts, revolutions, conspiracies, repressions, natural disasters and cataclysms, epidemics, etc. However, he does not predict tendencies in a strict sense. Understanding a tendency as a social and historical phenomenon naturally blends with a linear world outlook. For the cyclic worldview, such understanding is unnatural. In the cyclic world, there are actually no tendencies in the full sense of the word: any tendency exists only inside the cycle - it is either an ascending or a descending cycle movement. This is the conviction in recurrence of historical events that prevented Michel Nostradamus from predicting the tendencies of the nearest stages of the worldwide historical process, saying nothing of the distant future tendencies.

\section{Uncertainty of the Future: Prophecy, Foresight or Prediction}

A contemporary Nostradamus scholar Vladimir Rokhmistrov assumes that prophecy is possible only in case the future already exists. If the future does not exist, no prophecy is possible - what is only possible is to "mention the possible effect of deeds based on the knowledge of laws of development of any actions" (Rokhmistrov, 2006). In our opinion, the future does not exist in terms of events, it exists in terms of eventemes. Consequently, an event-driven prediction is impossible, what is only possible is an eventematic prediction.

Vladimir Rokhmistrov's position looks rather strange. On the one hand, he believes that a criterion of prophecy truth is a coincidence of all details with real events (Rokhmistrov, 2006a: 18). Then, one prophecy will match one event, for it is difficult to imagine various events with all details coincided. However, Vladimir Rokhmistrov does not only object to multiplicity of interpretations of each quatrain, but also insists on such multiplicity, if we understood it right. In his opinion, Michel Nostradamus's texts assume writer's and reader's 
co-authorship, what allows to create ever new interpretations of The Centuries. At the same time, binding the quatrains to real events specifies their sense (Rokhmistrov, 2006a: 17).

We believe that such an approach looks quite vulnerable. If we not only can but also must alter the sense of the quatrains depending on single events, then anyone can predict anything. We insist on the certainty of prophecy. Both a prophet predicts this and only this event or he does not predict anything. If somebody predicts an eventeme, this is not a prophecy, since to make such a "prediction" one must only know the repeating figures of historical eventivity.

A foresight and a prediction are scientifically sustainable; they are based on the analysis of tendencies, the probability theory. Ideally, they assume calculations (compare "predictive power of science", "scientific prediction", "and scientific forecast"). Prophecy is a mystic ability, which is based on superrational vision of future single events.

When trying to understand the prophecy phenomenon, Vladimir Rokhmistrov puts quite a correct question of the influence of the expressed prediction on the real course of events. Suppose, a negative prediction was expressed, which was followed by some preventive steps, and the prediction did not come true. Is such a prediction true? (Rokhmistrov, 2006a: 389). Vladimir Rokhmistrov suggests such a variant answer. If we extend to the maximum the boundaries of time duration back and forward, then we see the world in its six-dimensional (??! - A. Ye.) extension. We need this knowledge to prevent things that can cause a tragedy. It is as if we fixed a porch, so nobody would break a leg on it. Before we fix it, we realise what it will be like afterwards (Rokhmistrov, 2006a: 402-403).

Let us analyse Vladimir Rokhmistrov's considerations on the porch and the broken leg. Prophecies are possible in the predetermined world only. They are possible only in case it is predetermined whether this porch will be fixed or not, in case it is predetermined whether this man will break a leg or not on this porch, etc.

What is more, different worlds can have different variants predetermined, but every single world will have only one predetermined variant. All in all, there are four possible variants:

1. The porch will be fixed, but A will break a leg on it.

2. The porch will not be fixed, and A will break a leg on it.

3. The porch will be fixed, and A will not break a leg on it.

4. The porch will not be fixed, but A will not break a leg on it.

If out of a set of predetermined worlds we single out a subset of worlds where the individual A and the porch exist, then for the whole subset there are possible only the four variants mentioned above. Moreover, in every single world, out of this subset, only one of the four variants is realised.

In an unpredetermined world, this porch can be both fixed and unfixed, A can both break a leg on it or not, etc. That is for a subset of unpredetermined worlds the four combinatorial variants of the porch and the broken leg are not relevant at all.

The author of these lines believes that our world is exactly like this. We live in an unpredetermined world. Consequently, prophecies are impossible in our world, possible are foresights, predictions and prognoses.

Let us make an ally with Aristotle who believed that it is impossible to determine the truth of positive and negative judgments on accidental future events (Aristotel, 1978; 101, 19a 17-20). Such events are not predetermined. They "source from both decisions and certain activities"; therefore, accidental future events can have equal "possibility to be or not to be" (Aristotel, 1978; 101, 19a 7-11). If we agree to this, we admit that prophetic judgments in the strict sense of the word are impossible. 
In Aristotle's vivid description of possible argument of fortune-tellers, one can see, so to say, the "irony of history": "But nothing prevents anybody from stating, ten thousand years ahead, that this event will happen. And nothing prevents another fortune-teller from rejecting this prediction. And thus, it is necessary that any of these (predictions) was correct then. However, it does not matter whether anybody will express such contradiction or not, since it is clear that things will happen in their own way, not matter what one fortune-teller states and another one rejects" (Aristotel, 1978: 101, 18b 32-38).

In this imaginary argument, one of the fortune-tellers will prove right and the other one will prove wrong. However, is there any way for a fortune-teller to prove right? There is. First, many predictions should be made. Second, and most important, is that one should predict different, both opposite, variants of event outcomes. So, a set of predictions should be constructed just about like this: "town A will collapse", "town B will resist", "X will win a battle", "Y will lose a battle", "tyrant $\mathrm{Z}$ will come to power", "tyrant $\mathrm{Q}$ will be overthrown", etc. Third, one should express knowingly true predictions: "there will be a war", "there will be an epidemic", "there will be a drought", "there will be an earthquake", etc. A prophet making such "predictions" will surely be in a win-win situation. And if he manages to saturate his predictions with various controversial and at the same time mysterious details, his success will be stunning.

This is what Michel Nostradamus did.

\section{A Table of Quatrains}

We have built a table of all quatrains in The Centuries. The table reflects event-driven content of the quatrains, details as well as eventematic sense. As an example, we give a short fragment of the quatrain table.

\begin{tabular}{|c|c|c|c|}
\hline Number & Event-driven sense & Details & $\begin{array}{c}\text { Eventematic } \\
\text { sense }\end{array}$ \\
\hline $1 X .61$ & $\begin{array}{l}\text { A chieftain, with his } \\
\text { relatives (with his relatives } \\
\text { brought?) will be captured } \\
\text { on a seacoast; Messina siege; } \\
\text { bad rewards to the Maltese }\end{array}$ & $\begin{array}{l}\text { Seacoast, evil deed, chieftain, } \\
\text { tied up, relatives, brought, } \\
\text { Malta, Messina, besieged, badly } \\
\text { rewarded }\end{array}$ & $\begin{array}{l}\text { Chieftain's ar- } \\
\text { rest; unworthy } \\
\text { reward }\end{array}$ \\
\hline $1 X .62$ & $\begin{array}{l}\text { An outstanding leader of } \\
\text { crusaders will set free one } \\
\text { third of them }\end{array}$ & $\begin{array}{l}\text { Great man, Sheramonagore, } \\
\text { crusaders, dependent on, Oppi } \\
\text { entries (a town? opia?), Man- } \\
\text { dragora, Rogon, one third is set } \\
\text { free }\end{array}$ & $\begin{array}{l}\text { Part of the } \\
\text { troops is set free }\end{array}$ \\
\hline $1 X .63$ & $\begin{array}{l}\text { Protests, tears, sorrows and } \\
\text { changes on the French land }\end{array}$ & $\begin{array}{l}\text { Protests, tears, howl, loud cries, } \\
\text { terrible sorrows, changes, Nar- } \\
\text { bonne, Bayonne, Foix, Mars, } \\
\text { several rounds }\end{array}$ & War disasters \\
\hline $1 X .64$ & $\begin{array}{l}\text { A Balkan will cross the Pyr- } \\
\text { enees; there will take place } \\
\text { a most cruel land and sea } \\
\text { battle, impossible to escape }\end{array}$ & $\begin{array}{l}\text { A citizen of Ematia (a citizen of } \\
\text { Thessalia? A Balkan?), Pyrenean } \\
\text { mountains, will cross, Narbonne, } \\
\text { sea, land, dreadful battle, captain } \\
\text { (cardinal?), find no shelter }\end{array}$ & $\begin{array}{l}\text { Grand land and } \\
\text { sea battle }\end{array}$ \\
\hline
\end{tabular}




\begin{tabular}{|c|c|c|c|}
\hline $1 X .65$ & $\begin{array}{l}\text { A man will be captured and } \\
\text { taken abroad; there will burst } \\
\text { out discord; a great man will } \\
\text { be accused and a worthless } \\
\text { man will be glorified }\end{array}$ & $\begin{array}{l}\text { Surrender, Luna (town? Luna } \\
\text { location?), captured, taken, } \\
\text { foreign land, unripe fruit, great } \\
\text { discord, great man, accusations, } \\
\text { glorification }\end{array}$ & $\begin{array}{l}\text { Capture; ac- } \\
\text { cusations of the } \\
\text { great man, glory } \\
\text { to the worthless } \\
\text { man }\end{array}$ \\
\hline $1 X .66$ & $\begin{array}{l}\text { Peace, union, changes, end } \\
\text { of war; classes will rise and } \\
\text { fall; travel (pilgrimage), first } \\
\text { fruit; civil process, discus- } \\
\text { sions (citizens will continue } \\
\text { debates?) }\end{array}$ & $\begin{array}{l}\text { Peace, union, change, classes, } \\
\text { bottom-up, top-down, travel } \\
\text { (pilgrimage), first fruit, civil pro- } \\
\text { cess, discussions, end of struggle } \\
\text { (war?) }\end{array}$ & $\begin{array}{l}\text { Up and down } \\
\text { the wheel of } \\
\text { fortune }\end{array}$ \\
\hline $1 X .67$ & $\begin{array}{l}\text { People who came down from } \\
\text { the mountains will meet on a } \\
\text { rock; Peter carries a certain } \\
\text { message (?) (a protest?); Ro- } \\
\text { mans will unite religiously }\end{array}$ & $\begin{array}{l}\text { Mountain tops, Lieser suburbs, } \\
\text { port, Valent rock, one hundred } \\
\text { people, new palace, Peter, Cre, } \\
\text { Romans (citizens of Rome?), } \\
\text { notification, religious banner }\end{array}$ & $\begin{array}{l}\text { Religion unites } \\
\text { (a new proph- } \\
\text { et?) }\end{array}$ \\
\hline $1 X .68$ & $\begin{array}{l}\text { In the years of tyrant rule a } \\
\text { noble man (a woman?) will } \\
\text { be prosecuted; soldiers will } \\
\text { hide in the forest (make an } \\
\text { ambush?) }\end{array}$ & $\begin{array}{c}\text { Eimer mountains, darkness, no- } \\
\text { ble man (a woman?), grief, Sona, } \\
\text { Rona, soldiers, forest, shelter, St. } \\
\text { Lucia day, fearful throne }\end{array}$ & $\begin{array}{l}\text { A tyrant } \\
\text { prosecutes the } \\
\text { nobleman }\end{array}$ \\
\hline $1 X .69$ & $\begin{array}{l}\text { A disastrous hail will kill two } \\
\text { thirds of Grenoble refugees }\end{array}$ & $\begin{array}{l}\text { Wai fountain, Brel (Brels?), } \\
\text { arrogant men, Grenoble, Lyons, } \\
\text { Vienna, disastrous hail, one third } \\
\text { of survivors }\end{array}$ & $\begin{array}{l}\text { A natural } \\
\text { cataclysm kills } \\
\text { refugees }\end{array}$ \\
\hline $1 X .70$ & $\begin{array}{l}\text { On the day of accession to } \\
\text { the throne (coronation?) } \\
\text { Vienna citizens (Viennese?) } \\
\text { will be hacked to death by } \\
\text { Romans }\end{array}$ & $\begin{array}{l}\text { Thrust armour, flares, hidden, } \\
\text { Lyons, day of accession to the } \\
\text { throne, Vienna citizens (Vien- } \\
\text { nese?), hacked to death, Latin } \\
\text { cantons }\end{array}$ & Insidious attack \\
\hline
\end{tabular}

\section{References}

Aristotel. (1978) On the interpretation: v 4 t. T. 2. Moskva: My`sl.

Brind'Amour, Pierre. (1993) Nostradamus astrophile. Ottawa: Presses de l'Universite.

Carlstedt, Anna. (2005) La poesie oraculaire de Nostradamus: Langue, style et genre des Centuries. Stockholms universitet.

Deleuze, Gilles. (1995) The Logic of Sense. Moskva: "Akademiya".

Gruber, Elmar. (2003) Nostradamus. Sein Lebe, sein Werk und die wahre Bedeutung seiner Prophezeiungen. Bern: Scherz.

Hogue, John. (2002) Nostradamus: The Complete Prophecies. Trans. from English I. Havrilov. Moskva: Grand FAIR-press.

Koselleck, Reinhart. (2005) Futures Past: On the Semantics of Historical Time. Kyiv: Dukh i Litera.

Koselleck, Reinhart. (2006) Time Strata. A Study on History Theory. Kyiv: Dukh i Litera. Lemesurier, Peter. (2003) The Unknown Nostradamus. 
Nostradamus, Michel. (2010) The Prophecies of Nostradamus. Internet Sacred Text Archive. http://www.sacred-texts.com/nos/index.htm

Penzensky, Aleksey. (2007) Nostradamus. Moskva: Molodaya Gvardiya.

Rokhmistrov, Vladimir. (2006) All Life Moments Are Counted. Nostradamus M. The Centuries. Saint-Petersburg: Amfora, 369-411.

Rokhmistrov, Vladimir. (2006a) Nostradamus - The Mirror of History. Nostradamus M. The Centuries. Saint-Petersburg: Amfora, 5-30.

Shepheard, David. (1986) Pour une poetique du genre oraculaire: a propos de Nostradamus. Revue de Litterature Comparee n॰ 60. — January-March, 59-65.

Yeremenko, Aleksandr. (2005) History as Eventivity. In 2 vol. V. 1. Lugansk: RIO LAVD. 